DE DE GRUYTER OPEN
Journal of Intercultural Management

Vol. 6, No. 4, December 2014, pp. 181-190

DOI 10.2478/joim-2014-0044

Wioletta Czemiel-Grzybowska*

Bialystok University of Technology

\title{
Entrepreneurial orientation in family firms - management and intercultural development
}

\begin{abstract}
This paper has taken an insight to the systemic models of family business from the open systems perspective. I focus on family business system models and on the subsystems content of family system and ownership system in family business context. The paper claim that the open system perspective on intercultural family businesses has both theoretical and empirical implications on family business research. Family businesses have many reasons, including family conflicts over money, nepotism leading to wrong management, and infighting over the succession of power from one generation to the other. Regulating the family's roles as shareholders, board members, and managers is very important because it can help avoid these pitfalls.

This paper will discuss the importance of the openness of the company through five the attributes of enduring family businesses: ownership, family, business and portfolio governance, wealth management, foundation. Dimension of attributes success have taken family business like five jewelers.

Key words: entrepreneurship, family businesses, attributes of management, wealth management, portfolio governance.
\end{abstract}

\section{Introduction}

Openness system management of business family is a pro-development. This paper has taken an insight to the systemic models of family business from the open systems perspective. It focus on family business system models and on the subsystems content of family system and ownership system in family business context [Walicka M., 2013, pp. 441-448]. The paper claim that the open system perspective on family businesses has both theoretical and empirical implications on family business research. Family business concerns an open system that includes

\footnotetext{
*w.grzybowska@pb.edu.pl
} 
the family like a collective level doing business and securing continuity [Chrisman J.J., et.al. 2003, pp. 1045-1050]. Family businesses are possible although the family members own several companies, and that these companies may differ from each other very drastically. This system contains smaller pieces, like private businesses owned together with the family and businesses owned by individual family members. As the same time the open system, like the family business system is in solid relationship with its environment through each subsystem, such as businesses and family members. The family business development including both collective and individual reasoning and decisions concerning the control and responsibilities over businesses. Furthermore, ownership is often defined and treated as a relationship between the owner and the object. Ownership builds on the idea that ownership concerns human beings and ownable objects within an environment. But that the fundamental character of ownership is the power-influence position it gives to the owner in the social-material context. The Polish Model of Ownership should be included element directing the development of the family business system than it has been currently. This paper will discuss the importance of the openness of the company through five the attributes of enduring family businesses: ownership, family, business and portfolio governance, wealth management, foundation. Dimension of attributes success have taken family business like five Polish jewelers.

\section{Openness system models family business - current state of knowledge}

Theory about openness system models is a transdisciplinary approach. The main point is to study general principles of system functioning to be applied for all types of systems in all fields of research. The development in family business system models - a case study theoretical and empirical treatment of system models has been from closed to open systems [Kast and Rosenzweig, 1972, pp. 450-460]. Furthermore, it has been noted that the early system theorists didn't totally ignore the outer world in their reasoning. There are independent notions that it is difficult to find phenomena that are occurring in totally isolated or closed systems [Ashmos and Huber, 1987, pp. 610-621].

Habbershon and Pistrui [2002, pp. 230-234] has taken the unified systems approach to show performance that links the resources and capabilities generated in the enterprising families system with their potential for transgenerational wealth creation. Family firms are phenomena as a result of the involvement of the family through ownership, governance, management, and vision. Also, the family may have a vision for the transgenerational value creation [Chrisman J.J., et al., 2003, pp. 470-472]. The same familial coalition generates distinctive "familiness." Like trying to build a familiness model, researchers have used different perspectives and views to explain what familiness means in family business.

Researchers have defined and identified the construct of familiness as resources and capabilities that are possibilities to the family's involvement and interactions in 
the business [Habbershon T.G., et al, 2003, pp. 451-465; Zellweger, Eddleston and Kellermanns, 2010, pp.54-63; Frank et al., 2010, pp.12-130]. As well as Habbershon and Williams [1999, pp. 10-25] were among the first to introduce the term familiness later on, Chrisman, Chua and Litz [2003, pp. 467-470] defined it as resources and capabilities related to family involvement and interactions.

Although, the open-systems approach [Pieper T.M., Klein S.B., 2007, pp. 301$310]$ is used in combining the various elements of a family business. It means the unique characteristics and diversity of family businesses and addresses the activity among family business subsystems (multiple level of analysis My opinion that, the openness of the system takes place in the level of each subsystem, thus leading the system to be in constant interaction with business environment [CzemielGrzybowska W., 2013, pp.12]. The development of the family business should be understood by studying the behaviour of the individual members of the family and studying the needs of the eventual separate businesses within the family business structure.

This case studies by focus on optimization and quality together with the centralized open system management approach then results in efficient exploitation of existing family business activities. This is reflected in thesis: Polish family businesses identify their characteristics as attributes the success of their activity.

\section{Methodology of case study}

This study applies five case study of Polish jewelry family business. The first is Pracownia Jubilerska Stankiewicz Piotr. The business operates from three generations. Currently now, there have working Piotr, son Piotr, daughter Catherine and helps to spot the wife of Piotr Alexandra. The company took over from his father Piotr (Piotr), and that of his father (Piotr). Peter says that several generations is a positive attribute for management processes. Among the many positives, like a tradition, a stability and un experience, a charity. Also managing the permanent existence of the company "at home". One manager by management processes (the oldest in the family). Difficulties have risen like the limited financial resources and investment needs. Actually, the possibilities of international scholarship on the world, there are possibilities for the younger generation for the better future of the businesses.

The second is Anna Jewellery Department led by Anne, who took an interest from her dad. Now, Anna with her husband and two employees have operated production, trade and services jewelers. Focuses on conservative models, enriched with stones. She has participated in many international trades. She said, that a family business isn't a specific type of businesses activities. She has looked for the needs of the international market and also Sheis looking for talent among young employees. She was surprised attributes of management family businesses. 
Centrum Złotnicze Baranowscy is a business have taken by two generations of Pan Tadeusz Baranowski and Irene. They have employed three people from outside the family - Dealer selers.

They have plannig to involve their children in the future when they'll grow up. Baranowski said that, the main attribute of the family business is a tradition and ownership and separate interests. Baranowscy have 4 companies in the various industries.

The last family businesses is Atelier Jewelry. It is a family business for 10 years. Relates of several generations by the clothing industry. The business development and the search for a new market were created Atelier Jewellery. The owners are Jola and Kazimierz Polinski. They believe that the family attribute give significant advantage in the management and conduct of the investment business.

To be successful as both the company and the family grow, a family business must meet two intertwined challenges: achieving strong business performance and keeping the family committed to and capable of carrying on as the owner. Dimensions of activity (five) must work well and in synchrony harmonious relations within the family and an understanding of how it should be involved with the business, an ownership structure that provides sufficient capital for growth while allowing the family to control key parts of the business, strong governance of the company and a dynamic business portfolio, professional management of the family's wealth, and charitable foundations to promote family values across generations (Figure1).

I analyzed four companies from the jewelry industry: Pracownia Jubilerska Stankiewicz Piotr, Zakład Jubilerski Anna Modna, Centrum Złotnicze Baranowscy, Zakład Jubilerski Atelier. The form of data collection - interviews direct to 2013. Presented some of the results of research. Verification success factors like success attributes of family taken the five factors:

Figure 1. Dimension for success family firms

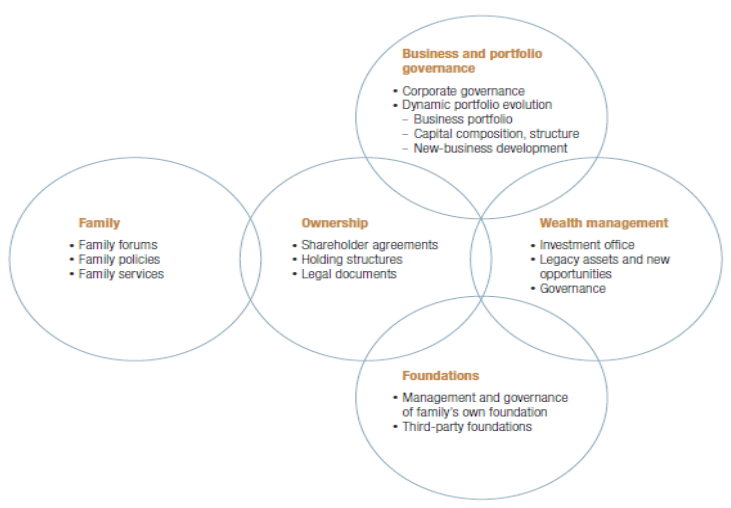

Source: Caspar C, Dias A, Elstrodt H., The five attributes of enduring family businesses, Mc Kinsley Quarterly, January 2010, p. 3-5. 
Large family businesses that survive for many generations make sure to permeate their ethos of ownership with a strong sense of purpose. Over decades, they develop oral and written agreements that address issues such as the composition and election of the company's board, the key board decisions that require a consensus or a qualified majority, the appointment of the CEO, the conditions in which family members can or can't work in their business, and some of the boundaries for corporate and financial strategy [Chrisman J.J., et al., 2010, pp. 1043-1058]. The continual development and interpretation of these agreements, and the governance decisions guided by them, may generations a sense of pride in the company's contribution to society. The family office may help organize regular gatherings that offer large families a chance to bond, to teach young members how to be knowledgeable and productive shareholders, and to vote formally or informally on important matters. It can also keep the family happy by providing investment, tax, and even concierge services to its members.

Ownership like maintaining family control or influence while raising fresh capital for the business and satisfying the family's cash needs is an equation that must be addressed [Daily C.M., Dollinger M.J., 1992, pp. 117-136]. It's a major source of potential conflict, particularly in the transition of power from one generation to the next.

In fact, some families decide to shut external investors out of the entire business and to fuel growth by reinvesting most of the profits, which requires good profitability and relatively low dividends. Others decide to bring in private equity as a way to inject capital and introduce a more effective corporate governance culture.

Business and portfolio governance is important dimension for success business enterprise. With clear rules and guidelines concluding, family enterprises can get on with their business strategies [Bartholomeusz S., Tanewski G.A., 2006, pp. 245-267]. Two success factors show up frequently: strong boards and a long-term view coupled with a prudent but dynamic portfolio strategy. Large and durable family businesses tend to have strong governance. Members of these families avoid the principal-agent issue by participating actively in the work of company boards, where they monitor performance diligently and draw on deep industry knowledge gained through a long history. Successful family companies usually seek steady long-term growth and performance to avoid risking the family's wealth and control of the business [Carney M., 2005, pp. 249-265]. This approach tends to shield them from the temptation-which has recently brought many corporations to their knees—of pursuing maximum short-term performance at the expense of long-term company health. A longer-term planning horizon and more moderate risk taking serve the interests of debt holders too, so family businesses tend to have not only lower levels of financial leverage but also a lower cost of debt than their corporate peers do (long- term portfolio view) [Miller D, et al. 2006, pp.73-80]. 
Wealth management - beyond the core holdings, families need strong capabilities for managing their wealth, usually held in liquid assets, semiliquid ones (such as investments in hedge funds or private-equity funds), and stakes in other companies. By diversifying risk and providing a source of cash to the family in conjunction with liquidity events, successful wealth management helps preserve harmony [Ireland R.D., et al., 2003, pp. 963-989]. The five key factors that increase the chances of success: a high level of professionalism, with institutionalized processes and procedures; rigorous investment and divestment criteria; strict performance management; a strong risk-management culture, with aggregated risk measurement and monitoring; and thoughtful talent management [Kellermanns F., Eddleston K. , 2006, pp. 809-830]. Charity is an important element in keeping families committed to the world business, by providing meaningful jobs for family members who don't work in it and by promoting family values as the generations come and go. Sharing wealth in an act of social responsibility also generates goodwill toward the business. Foundations set up by entrepreneurial families represent a huge share of philanthropic giving around the world [McConaughy, et al., 2001, pp. 31-40].

\section{Final remarks}

System approach for family business is very popular in all fields of research. Case studies have referred to four family businesses from the jewellery industry from at least 2 generations. The all companies have development oriented to achieve not only economic profit but also social profit. The behavioral approach to economic factors have taken the individual attributes of their businesses. In my opinion, the companies observe their management attributes but its different ways to competitive advantage. None of the subjects $(0 \%)$ did not indicate that it operates a charity and didn't promote the social values. However, $75 \%$ (3 from 4 businesses) indicated that family attribute is a factor in the business and only one person said that this attribute reduces the growth of its business.

Table 1. Attributes of enduring family businesses - case study for five jewelers

\begin{tabular}{|c|c|c|c|c|c|c|c|c|c|c|}
\hline \multirow{3}{*}{$\begin{array}{l}\text { Name of } \\
\text { family } \\
\text { business }\end{array}$} & \multicolumn{10}{|c|}{ Attributes of enduring family businesses } \\
\hline & \multicolumn{2}{|l|}{ Family } & \multicolumn{2}{|c|}{ Ownership } & \multicolumn{2}{|c|}{$\begin{array}{l}\text { Business } \\
\text { and portfolio } \\
\text { governance }\end{array}$} & \multicolumn{2}{|c|}{$\begin{array}{l}\text { Wealth man- } \\
\text { agement }\end{array}$} & \multicolumn{2}{|c|}{ Foundations } \\
\hline & \begin{tabular}{l|} 
Strong \\
attri- \\
bute
\end{tabular} & $\begin{array}{l}\text { Weak } \\
\text { attri- } \\
\text { bute }\end{array}$ & $\begin{array}{l}\text { Strong } \\
\text { attri- } \\
\text { bute }\end{array}$ & $\begin{array}{l}\text { Weak } \\
\text { attri- } \\
\text { bute }\end{array}$ & $\begin{array}{l}\text { Strong } \\
\text { attri- } \\
\text { bute }\end{array}$ & $\begin{array}{l}\text { Weak } \\
\text { attri- } \\
\text { bute }\end{array}$ & $\begin{array}{l}\text { Strong } \\
\text { attri- } \\
\text { bute }\end{array}$ & $\begin{array}{l}\text { Weak } \\
\text { attri- } \\
\text { bute }\end{array}$ & $\begin{array}{l}\text { Strong } \\
\text { attri- } \\
\text { bute }\end{array}$ & $\begin{array}{l}\text { Weak } \\
\text { attri- } \\
\text { bute }\end{array}$ \\
\hline $\begin{array}{l}\text { (1)Pra- } \\
\text { cownia } \\
\text { Jubilerska } \\
\text { Stankie- } \\
\text { wicz Piotr }\end{array}$ & + & - & - & + & - & + & + & - & - & + \\
\hline
\end{tabular}




\begin{tabular}{|c|c|c|c|c|c|c|c|c|c|c|}
\hline $\begin{array}{l}\text { (2) } \\
\text { Zakład } \\
\text { Jubilerski } \\
\text { Anna } \\
\text { Modna }\end{array}$ & - & + & - & + & + & - & - & + & - & + \\
\hline $\begin{array}{l}\text { (3) Cen- } \\
\text { trum } \\
\text { Złotnicze } \\
\text { Ba- } \\
\text { ranowscy }\end{array}$ & + & - & + & - & - & + & - & + & - & + \\
\hline $\begin{array}{l}(4) \\
\text { Zakład } \\
\text { Jubilerski } \\
\text { Atelier }\end{array}$ & + & - & + & - & - & + & - & + & - & + \\
\hline Total: & 3 & 1 & 2 & 2 & 1 & 3 & 1 & 3 & 0 & 1 \\
\hline $\begin{array}{l}\text { Percent- } \\
\text { age: }\end{array}$ & 75 & 25 & 50 & 50 & 25 & 75 & 25 & 75 & 0 & 100 \\
\hline
\end{tabular}

Source: Own researches

+ existent attribute in family business

- non existent attribute in family business

Ownership attribute is indicated by the two businesses like strong management attribute, which is a competitive advantage, and by 2 family businesses like the weakness attribute of the jewellery development.

Business and portfolio governance in the family businesses is the attribute of management development of 3 from 4 businesses). At the same time it has limited the management processes in a family entity.

Wealth management - limited the processes associated with risk management in the family businesses. Despite the talent management, is'nt enough diversified the business risk. Hence, as much as $75 \%$ (3 from 4 businesses) indicates this attribute gives the weak effects of management.

Table 1. The impact of attributes on the processes of management and growth opportunities (investment) in the family businesses in the opinions of entrepreneurs

\begin{tabular}{|c|c|c|c|c|c|c|c|c|c|c|}
\hline \multirow{2}{*}{} & \multicolumn{9}{|c|}{ Attributes of enduring family businesses } \\
\cline { 2 - 13 } & \multicolumn{2}{|c|}{ Family } & \multicolumn{2}{c|}{ Ownership } & $\begin{array}{c}\text { Business } \\
\text { and portfolio } \\
\text { governance }\end{array}$ & $\begin{array}{c}\text { Wealth manage- } \\
\text { ment }\end{array}$ & \multicolumn{2}{c|}{ Foundations } \\
\cline { 2 - 13 } & $\begin{array}{c}\text { Manage- } \\
\text { ment }\end{array}$ & $\begin{array}{c}\text { Invest- } \\
\text { ment }\end{array}$ & $\begin{array}{c}\text { Manage- } \\
\text { ment }\end{array}$ & $\begin{array}{c}\text { Invest- } \\
\text { ment }\end{array}$ & $\begin{array}{c}\text { Man- } \\
\text { agement }\end{array}$ & $\begin{array}{c}\text { Invest- } \\
\text { ment }\end{array}$ & $\begin{array}{c}\text { Manage- } \\
\text { ment }\end{array}$ & $\begin{array}{c}\text { Invest- } \\
\text { ment }\end{array}$ & $\begin{array}{c}\text { Manage- } \\
\text { ment }\end{array}$ & $\begin{array}{c}\text { Invest- } \\
\text { ment }\end{array}$ \\
\hline$(1)$ & + & - & + & + & - & + & + & - & + & - \\
\hline$(2)$ & + & + & + & + & - & - & + & + & + & - \\
\hline$(3)$ & + & - & + & - & - & + & + & + & + & - \\
\hline$(4)$ & + & - & + & - & - & + & + & + & - & - \\
\hline
\end{tabular}

Source: Own research. 
(1) Pracownia Jubilerska Stankiewicz Piotr; (2) Zakład Jubilerski Anna Modna; (3) Centrum Złotnicze Baranowscy; (4) Zakład Jubilerski Atelier

Entrepreneurs - business owners taken different ways to the impact of the analyzed attributes for management and investment. Entrepreneurs indicate that the following attributes are the most important for management and development in family businesses: family, ownership i wealth management. In the opinion of entrepreneurs any attributes haven't got the impact for investments. Without the wealth management, - the most important attribute of enduring family businesses.

Whereas the first statement specifies the process of intentionality among family members and the second specifies the vehicle by which intentions might be realized, the final statement closes the loop by providing a specific feedback mechanism between performance and intentionality.

I argued that with some extensions it can be made applicable to all family firms. Furthermore, I attempted to show that by integrating the concepts of intentionality, vision, behavior, and familiness, there appears to be an opportunity to develop a theory of the family firm from these beginnings.

\section{Summary}

According to the Foundation Family Businesses, until 60 percent businesses with 2.2 million active Polish businesses are the family businesses. They have produced 67 percent GDP. Some of them, especially those at the beginning of the $90 \mathrm{~s}$ the last century.

Every case studies of family businesses indicate that the attributes of the family isn't always indicated like important in the processes of governance. However, the jewelry businesses are the specific types of business activity, The most part of them there are family businesses. The jewelry industries need valuable materials and, the financial cost for the start business activities.

In summary, this paper contributes to the understanding of the attributes of enduring intercultural family businesses into the discussion about family businesses performance and family firm heterogeneity. For intercultural managerial practice, our findings highlight the special role of family firms as well as the positive performance impact achieved by having an organization with a strong orientation to intercultural family attributes.

\section{Bibliography}

Ashmos, D.P., Huber G.P (1987) 'The Systems Paradigm in Organization Theory: Correcting the Record and Suggesting the Future', Academy of Management Review 12(4), pp.610621.

Bartholomeusz, S., Tanewski G. A.. (2006) 'The Relationship between Family Firms and Corporate Governance', Journal of Small Business Management 44(2), pp. 245-267. 
Carney M. (2005) 'Corporate Governance and Competitive Advantage in Family-controlled Firms', Entrepreneurship: Theory and Practice 29(3), pp. 249-260.

Chrisman, J.J., Chua J. H., Pearson A. W., Barnett T. (2010) 'Family Involvement, Family Influence, and Family-centered Non-economic Goals in Small Firms', Entrepreneurship Theory and Practice 34, pp.1045-1050.

Chrisman J.J., Chua J. H., Steier. L. P. (2003) 'An Introduction to Theories of Family Business', Journal of Business Venturing 18(4), pp. 441-448.

Chrisman J.J., Chua J.H., Litz R. (2003) 'A Unified Systems Perspective of Family Firm Performance: An Extension and Integration', Journal of Business Venturing 18(4), pp. 470-472.

Czemiel-Grzybowska W., 'Barriers to financing small and medium business in Poland', Journal of Business and Economic Horizons, 2013, pp.12.

Daily C.M., Dollinger M. J. (1992) 'An Empirical Examination of Ownership Structure in Family and Professionally Managed Firms’, Family Business Review 5(2), pp. 117-136.

Frank H., Lueger M., Nose L., Suchy D. (2010) 'The Concept of 'Familiness' Literature Review and Systems Theory-based Reflections', Journal of Family Business Strategy 1, pp.119130.

Habbershon T.G., Williams M. L. (1999) 'A Resource-based Framework for Assessing the Strategic Advantages of Family Firms', Family Business Review 12(1), pp.10-25.

Habbershon T.G., Pistrui J. (2002) 'Enterprising Families Domain; Family-Influenced Ownership Groups in Pursuit of Transgenerational Wealth', Family Business Review 15(3), pp. 230-234.

Habbershon T. G., Williams M.,MacMillan I.C. (2003), 'A Unified Systems Perspective of Family Firm Performance’ Journal of Business Venturing 18, pp.451-465.

Ireland R.D., Hitt M.A., Sirmon D.G. (2003) 'A Model of Strategic Entrepreneurship: The Construct and its Dimensions’, Journal of Management 29(6), p. 963-989.

Kast F.E., Rosenzweig J.E. (1972) 'General System Theory: Applications for organization and Management', The Academy of Management Journal 15(4), pp. 450-460.

Kellermanns, F., Eddleston K. (2006), 'Corporate Entrepreneurship in Family Firms: A Family Perspective’, Entrepreneurship Theory and Practice 30(6), pp. 809-830.

McConaughy D.L., Matthews C.H., Fialko A. S. (2001), 'Founding Family Controlled Firms: Performance, Risk, and Value', Journal of Small Business Management 39(1), pp. 31-49.

Miller D., Le Breton-Miller I. (2006) 'Family Governance and Firm Performance: Agency, Stewardship, and Capabilities', Family Business Review 19(1), pp. 73-87.

Pieper T.M., Klein S. B. (2007) 'The Bulleye; A Systems Approach to Modeling Family Firms', Family Business Review 20(4), pp. 301-310.

Walicka M. (2013) Life Science Business Management - Financial Aspects, [in(inlove) Knowledge - Economy - Society Challenges Of The Contemporary Management, (Ed. by Anna Malina, Renata Oczkowska, Tomasz Rojek), Uniwersytet Ekonomiczny w Krakowie, Cracow, pp. 325-336. 
Zellweger T.M., Eddleston K.A., Kellermanns F. W (2010) 'Exploring the Concept of Familiness: Introducing Family Firm Identity', Journal of Family Business Strategy 1(1), pp. 54-63. 